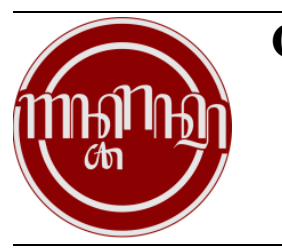

\title{
GHÂNCARAN: JURNAL PENDIDIKAN BAHASA DAN SASTRA INDONESIA
}

http://ejournal.iainmadura.ac.id/index.php/ghancaran E-ISSN : 2715-9132 ; P-ISSN: 2714-8955 DOI 10.19105/ghancaran.vi.5317

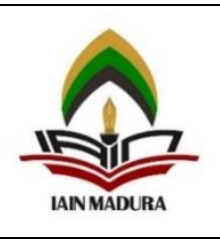

\section{Kebangkitan Lima Karakter Orang Madura Pasca Corona}

\author{
Ardhie Raditya*, Naufalul Ihya' Ulumuddin**
}

*Prodi Sosiologi, Fakultas IImu Sosial dan Hukum, Universitas Negeri

Surabaya, dan Sekolah Kritis Younesa [V]

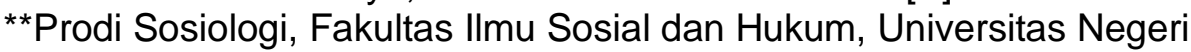

Surabaya, dan Sekolah Kritis Younesa [V]

Alamat surel: diditz.kristina@gmail.com; younesa.movement@gmail.com

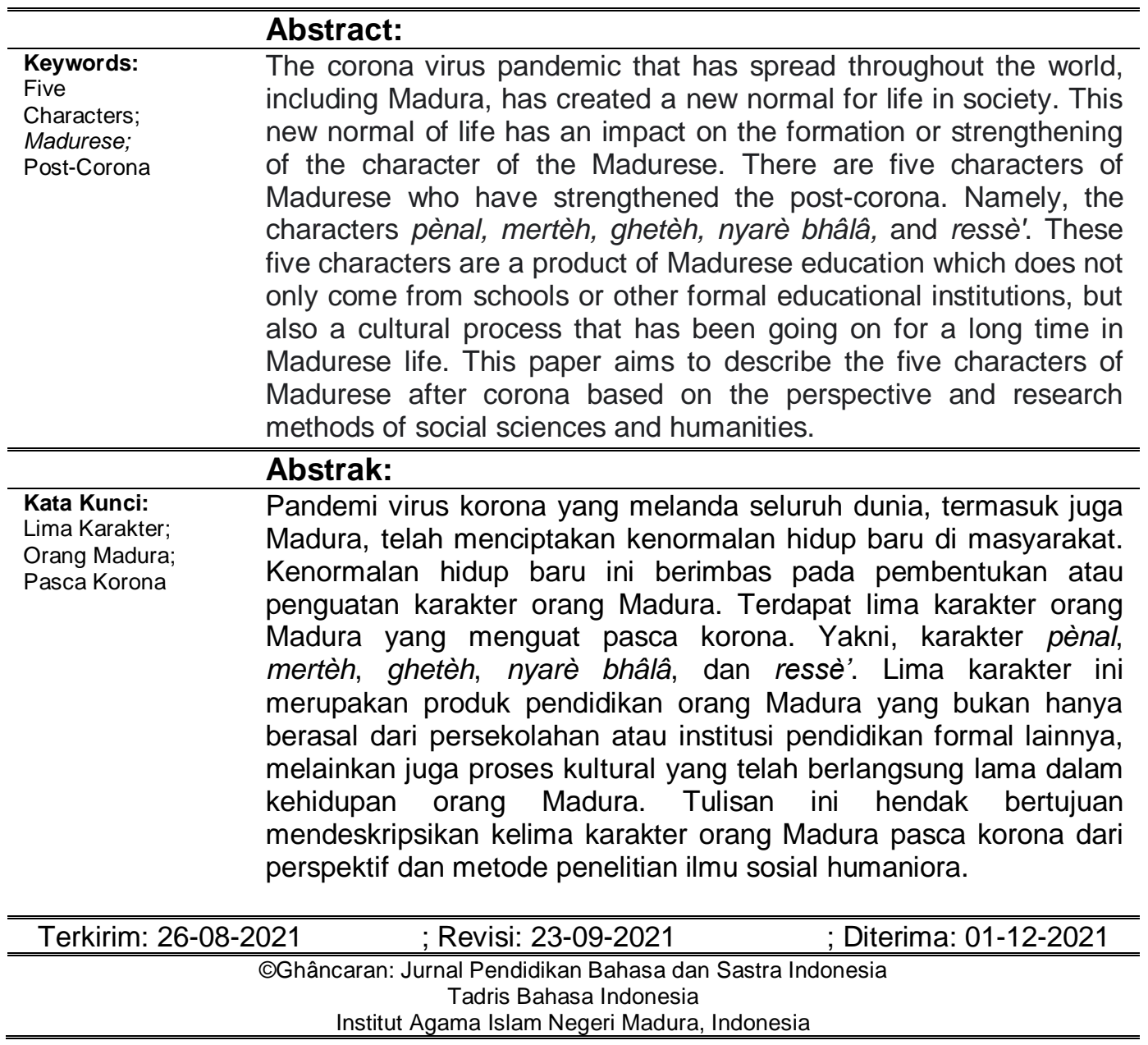




\section{PENDAHULUAN}

Covid-19, kadangkala disebut juga virus korona, telah melanda Indonesia selama dua musim lebaran, terhitung sejak 2020 hingga 2021. Suasana berubah mencekam seakan sedang perang melawan musuh tidak kasat mata, virus korona. Setahun silam, di Surabaya, kota besar yang terdekat dengan Madura, pernah dianggap menyandang status 'zona hitam', suatu istilah kondisi darurat karena korban terpaparnya melebihi angka 2000-an. Setelah Surabaya, Madura pada sisi sebelah baratnya, yang posisi geografisnya berhadap-hadapan dengan kota pahlawan, Juni 2021 lalu menghadapi korona varian baru, varian Delta. Penyekatan darurat untuk ke luar - masuk orang Madura segera dilakukan oleh pemerintah, dari barat hingga ke timur pulaunya. Gerakan pro kesehatan dan pro kehidupan semakin gencar dilakukan di Madura. Tidak hanya gerakan menggunakan masker, mencuci tangan, dan menghindari kerumunan, melainkan juga gerakan pembatasan mobilitas orang Madura berskala besar dan permohonan akbar kepada Tuhan agar terbebas dari berbagai penyakit mematikan. Orang Madura yang dikenal bangsa perantau dan gemar berpetualang terpaksa harus sesering mungkin berada dalam rumah, agar terhindar dari keganasan korona. Apakah pandemi Covid-19, yang berbulan-bulan membatasi pergerakan lintas geografis dan sosial seluruh rakyat Indonesia, berdampak terhadap perubahan karakter orang Madura ? Apabila perubahan karakater berskala besar ini sungguh nyata, maka menurut pendapat Hunter (2000), masyarakat tersebut sedang menghadapi 'kematian karakter', karena pembaruan nilai-nilai maupun 'restorasi' nilainilai yang menjungkirbalikkan pegangan nilai-nilai kehidupan yang lama. Inilah topik utama tulisan kami tentang karakter orang Madura pasca korona, walaupun pandemi ini belum bisa diprediksi kapan akan cepat berlalu di seluruh penjuru negeri.

Karakter berbeda dengan personalitas yang umumnya dipakai dalam disiplin psikologi. Kupperman (1991) memberikan penjelasan dengan sangat hati-hati mengenai konsep karakter dan personalitas. Menurutnya, dalam kamus besar Oxford bahasa Inggris istilah karakter pada dasarnya mengacu pada suatu instrumen untuk menandai, mewarnai, memberi petunjuk, atau menggali, stempel, kesan, dan pembeda ekologi. Sementara, personalitas berarti ciri psikologis orang per orang (person) yang sifatnya pembeda masing-masing individu yang mungkin saja berupa watak, kepribadian, motivasi, dan lain sebagainya yang menjadi sifat internal dari setiap orang. Piaget (1947), misalnya, menjelaskan bahwa psikologi berkaitan erat dengan organisme biologis, seperti sensor motorik, kognisi, dan perkembangan mental. Skinner (1971 dan 2005), tokoh dunia yang mempopulerkan hukum psikologi pergerakan 
individu, berpendapat bahwa personalitas merupakan prinsip behavioristik yang didasarkan pada hukum kausalitas, sehingga kita bisa menjelaskan hubungan antara struktur individual, seperti warna kulit, rambut, bentuk tubuh, dan lainnya, serta dampaknya terhadap prilaku menyimpang atau kebahagiaan, misalnya wajah pemurung salah satu ciri seorang penjahat, atau obesitas menunjukkan seseorang yang gemar makan. "Prilaku ini produk organisme prilaku yang terbentuk dari proses genetis", kata Skinner. "Karena itu, diperlukan kondisi-kondisi penguatan yang memicu stimulus psikologis, supaya menghasilkan respon terhadapnya dalam bentuk prilaku positif atau negatif" (Skinner, 1971: 20). Personalitas diarahkan oleh aparatus mental berdasarkan prinsip kesenangan dan meminimalisir penderitaan, sehingga dari sana sifat kesedihan, kebahagiaan, sensasional, dan kualitas kecantikan terpancar dari dalam diri seseorang (Freud, 1962: 30-31).

Karakter bukan produk psikologis sebagaimana personalitas. Karakter merupakan garis pembatas mengenai kebiasaan dan kecenderuran pikiran yang muncul ke dalam tindakan sosial sebagai bagian penting dari ekspektasi masyarakat terhadap domain moral yang menjadi acuan keberadaban publik (Kupperman, 1991: 14). Istilah karakter mulai mendunia sejak abad ke-19, setelah abad sebelumnya disinonimkan dengan istilah martabat, reputasi, dan jati diri. Terdapat tiga macam strategi untuk memahami konsep karakter ini, yakni psikologis (pilihan bebas, dan bukan berasal dari deprivasi instingtual), neoklasikal (nilai kekeluargaan), serta komunitarian (berbagi pengalaman mengenai kehidupan bersama), dengan demikian karakter bukan sesuatu yang abstrak, melainkan termanifestasikan dalam beragam praktik dan variasi kultural secara kontekstual (Hunter, 2000: 21). Karena pentingnya karakter bagi tatanan sosial dan normalisasi kehidupan, maka sejak Presiden Bill Clinton dan George Bush berkuasa di Amerika, kebijakan pendidikan dipusatkan pada pendidikan karakter supaya tercipta masyarakat dan warga negara yang baik. Sejak tahun 1996, anggaran pelaksanaan pendidikan karakter tersebut kurang lebih mencapai $\$ 375.000$, naik dari $\$ 250.000$ pada tahun sebelumnya. Setidaknya, terdapat 4 macam proposisi penting mengenai pendidikan karakter. 1) karakter terlokasi di komunitas mengenai responsibilitas; 2) sifat karakter selalu stabil dan situasional; 3) karakter bermanfaat bagi semua orang; 4) karakter terbentuk dari proses reflektif dan induktif mengenai pertimbangan moralitas (Smagorinsky dan Taxel, 2005: 17). Para intelektual pendidikan yang tergabung ke dalam pusat studi etika dan karakter di Universitas Boston mengeluarkan tujuh butir manifesto pendidikan karakter. 1) pendidikan menjadi kekuatan utama penguatan kapasitas moral, sehingga berbagai pihak yang terlibat 
menyadari tentang nilai kebaikan dan keburukan; 2) para orang tua adalah pendidik moral utama bagi anak-anak, sekaligus menjadi mitra pendidik moral di sekolah; 3) pendidikan karakter menumbuhkan kebijaksaan; 4) guru dan sekolah harus mendukung misi orang tua dan komunitas dalam penanaman moral; 5) pendidikan karakter bukan slogan belaka, karena harus menjadi praktik sosial dalam setiap lini kehidupan; 6) setiap komunitas ikut ambil bagian dalam penyebarluasan kearifan moral melalui aktivitas seni, cerita luhur, biografi, dan sejarah; 7) anak-anak muda harus senantiasa diingatkan betapa pentingnya karakter bagi sehari- hari hidup mereka (Ryan dan Thayer, 1996: 4).

Domain moral umumnya mengacu pada tata nilai. Seseorang yang bermoral berarti dia memiliki kekuatan nilai. Ini indikasi seseorang berkarakter. Nilai secara definitif berarti sesuatu yang dianggap sangat berharga atau dicintai dalam kehidupan manusia. Menurut Kupperman (1999: 5) dalam kebiasaan umum masyarakat terdapat tiga macam nilai yang menjadi tujuan hidup, yakni gambaran keutamaan hidup (misalnya cinta, hubungan sesama, dan kesuksesan, pencapaian atau prestasi), pengalaman berkesan dan tidak terlupakan (misalnya, peristiwa yang membekas dan mungkin saja momentumnya tidak bisa terulang), dan kebendaan (seperti, uang, barang mewah, gelar, serta objek lain yang menjadi dambaan banyak orang). Tetapi, menjadi seseorang atau sekelompok orang yang berkarakter dengan mempertahankan tujuan hidup yang bernilai ini tidaklah mudah. Karena, selalu ada gangguan yang biasanya muncul dari emosional manusia. Emosi merupakan hasutan rasionalitas manusia karena di dalamnya melibatkan unsur perasaan seseorang, sehingga kemunculan rasa iri-dengki, merasa unggul dari orang lain, takut terjungkal dari kompetisi kemewahan, dan lain sebagainya, bisa menghancurkan tatanan moral yang menjadi standar hidup masyarakat (Sartre, 1948; Kupperman, 1999). Walaupun, emosi dalam arti keputusan estetis, seperti simpati, rasa malu, tahu diri, dan peduli, juga berkontribusi memperkuat karakter karena masyarakat menuntut anggotanya mengendalikan energi psikis negatif yang mengancam stabilitas relasi sosial, sehingga mereka disebut berintegritas karena daya nilai altruistik, yakni berani dan setulus hati mengutamakan kepentingan umum daripada keinginan pribadinya (Sabini dan Silver, 1998; Hunter, 2000; Kupperman, 2007).

Pengalaman visual (melihat dan menghayati) juga menjadi faktor penentu derajat lemah tidaknya kekuataan moral. Menurut Kupperman (1999) pengalaman visual bersumber dari apa yang nyata terlihat dan seakan "terlihat seperti". Ini menghasilkan dua prinsip dasar moralitas: pengalaman bernilai dan keputusan bernilai. Yang pertama 
mengacu pada hasil pemikiran dan pengalaman empiris sebagai dasar pengetahuan moral, sedangkan yang kedua mengacu pada motivasi sebagai koordinasi sosial dan berdampak pada penentu keputusan moral. Sire (2004: 23-24) menjelaskan bahwa derajat moral seringkali terkait dengan sesuatu yang dianggap baik, pantas, dan benar berdasarkan pandangan dunia (worldview). Baginya, pandangan dunia adalah perspektif fundamental seseorang dalam membahas dan menilai berbagai persoalan kehidupan. Karena terkait dengan seperangkat nilai, kepercayaan, gagasan, gerak hati, dan imajinasi, maka pandangan dunia pada dasarnya manifestasi dari budaya yang mendasari gerak pikiran dan jiwa manusia (Hunter, 2010). Pandangan dunia ini dapat berasal dari agama yang mengajarkan kita tentang konsep alam semesta, kesucian, doktrin kebenaran, simbol, dan pengorbanan (Naugle, 2002; Howard, 2011), ilmu pengetahuan dan historis yang mengasah kemampuan menganalisa, mengevaluasi, menjelaskan, memprediksi, dan memahami perubahan sosial (Aerts, D'hooghe, dan Note, 2005; Sire, 2004). Dengan demikian, pembentukan karakter terjadi secara dialektis resiprokal antara pandangan dunia seseorang dan kehidupan sosial, individu bertindak di dalam dunia dan dunia bertindak balik padanya, sehingga tidak mungkin urusan karakter diserahkan sepenuhnya pada persekolahan atau pendidikan formal (Hunter, 2000). Sekalipun pendidikan menjadi pusat transmisi moral lintas generasi, tetapi pendidik yang bernilai dan berkomitmen moral bagi tumbuhnya generasi muda anti sosial bukan semata-mata guru, melainkan juga para orang tua, pemimpin, komunitas, tokoh agama, tokoh masyarakat, seniman, dan teman sebaya (Schwartz, 2002; Damon dan Colby, 2015), yang peranan strategis mereka sejatinya didukung dengan tiga kekuatan yang saling berkelindan: sejarah, lingkungan geografis, dan seperangkat kultural (Hutcheon, 1999). Setiap orang selalu berusaha menjadikan diri mereka bernilai bagi lingkungan sekitarnya. Tetapi, mereka yang lahir dan dibesarkan dalam lingkungan masyarakat atau keluarga yang tuna kasih sayang punya kecenderungan melakukan penyimpangan moral, karena nilai-nilai hidup yang mereka yakini adalah berusaha mengintimidasi orang lain demi bertahan hidup di dalam dunia yang mereka anggap sarat ancaman dan diselubungi kehampaan.

Pandangan tentang moral, yang tentu saja berimplikasi terhadap pondasi dasar karakter, sepanjang sejarah pemikiran ilmu sosial humaniora seringkali memicu perang budaya di antara para perumusnya. Di Amerika, perang budaya mengenai pemahaman moral terjadi antara para kelompok ortodoks dan progresif. Kelompok ortodoks mengklaim bahwa moral tidak mungkin berubah karena sifatnya yang universal, sebaliknya kelompok progresif menganggap moralitas sifatnya kontekstual, sehingga 
terbuka dengan perubahan sesuai dengan perbedaan pemahaman kelompok penganutnya (Hunter, 1991). Konsekuensi perang budaya ini memunculkan dilema moral masyarakat. Logika dilema moral ini terjadi karena kondisi bineritas antara dua hal yang bersitegang, seperti menghormati agama tetapi menggugat kepentingan penganutnya, memakai kerangka moral tetapi tidak bermoral, dan bersikap ambivalen terhadap elit-elit masyarakatnya sekalipun tindakan para elit tersebut melanggar kaidah-kaidah moral (Thomson, 2010). Secara filosofis, moral menjadi validitas universal yang imperatif kategoris bagi semua orang, di mana dan kapan saja. Pemikiran yang didasarkan pada filsafat etika Kantian ini menjadikan moralitas sebagai supremasi tertinggi dalam perjalanan hidup karenanya mengikat setiap orang agar apa yang mereka pikiran dan lakukan terkoordinasi dengannya (Kerstein, 2002). Supremasi moral tertinggi tidak membutuhkan objek, baik didasari maupun tidak, karena hukum moral tersebut merupakan bentuk hukum yang murni, objektif, sehingga setiap orang tidak perlu lagi bertanya apa yang sebaiknya dilakukannya, melainkan mereka harus berlaku taat terhadapnya (Deleuze, 1984). Doktrin kebajikan ini bisa dipahami dengan contoh sederhana mengenai cinta diri dan kesombongan diri yang terkoordinasikan dengan orang lain. Cinta diri adalah bentuk egoisme umum karena menganggap diri paling benar sendiri, sehingga alasan tindakannya dan pendapat orang lain harus tertuju pada upaya memuaskan dirinya. Sedangkan, kesombongan diri punya kecenderungan mencederai martabat orang lain, acuh tak acuh, bahkan seenaknya memberikan 'hukuman' kepada orang lain, supaya orang lain selalu tunduk dan melayaninya (Reath, 2006). Seseorang berkarakter berusaha memegang teguh supremasi moral dan senantiasa menjauhkan diri dari tindakan tercela itu karena mengutamakan ego transendental. Ego transendental tidak memiliki dunia, hanya saja keberadaanya terbatas di dalam dunia, tanpa tergoda penampakan empiris (fenomena), sehingga membuka diri pada suatu totalitas yang tidak tampak (noumena), seperti eksistensi teologis (Abdullah, 1992). Ego transendental ini bisa dipahami dari kebiasaan (habitual) dan tindakan akratik (akrasia: lemahnya kehendak) menanam kebaikan. Seseorang yang sepanjang sejarah hidupnya tidak pernah bersentuhan dengan narkoba, misalnya, tiba-tiba terjebak dalam lingkaran setan narkoba, tidak bisa disebut kebiasaan, melainkan akratik, karena pada suatu waktu dia menyesali dan terbebas darinya (Thero, 2006: 118). Kerendahatian dan keramahan adalah contoh lain tentang karakter berdasarkan disposisi moral Kantian. Keduanya bagi sebagian orang bisa jadi gambaran lemahnya karakter seseorang karena membuka peluang bagi orang lain memperdayainya, tetapi kerendahatian dan keramahan dalam moralitas Kantian 
menunjukkan kebiasaan menghormati harga diri orang lain karena dia meyakini bahwa setiap manusia memiliki keterbatasan, sehingga meremehkan maupun merendahkan orang lain adalah tindakan cacat moral atau amoral (Grenberg, 2005: 143-144; Damon dan Colby, 2015: 161-162).

Hegel menggugat filsafat moral Kantian karena mengabaikan kesadaran subjek. Apa yang dianggap ego transedental Kantian sebagai bagian terpenting dari supremasi moral telah menyimpang dari status manusia sebagai subjek berakal, yang kesadarannya berkorespondensi terhadap objek dan bagi dirinya. Tidak mungkin substansi dari fenomena menjadi absolut atau transedental tanpa melibatkan dialektika kesadaran, sehingga prinsip imperatif kategoris moral yang mendasari keutuhan karakter seseorang mengandaikan tidak berdayanya kesadaran yang menyadari adanya kekuatan moral, artinya sesuatu yang eksternal dari diri seseorang hanyalah berfungsi bagi dirinya (thing-in-itself) dan tidak berfungsi bagi apa pun di luar dirinya (being-in-itself). Hukuman, misalnya, tidak bisa menjadi hukum moral objektif apabila tidak memberi arti bagi kesadaran pelanggarnya. Hal ini sebagaimana prinsip dunia terbalik dari Hegel bahwa kebaikan mengandung keburukan, artinya keadilan, sebagaimana tujuan hukum objektif, tidak mungkin menjadi aktual bagi semua orang apabila keadilan hanya berlaku abstrak (Gadamer, 1976: 50-51). Verene (2007: 56-57) memberikan penjelasan tentang dasar dialektika kesadaran Hegelian mengenai moral. Untuk memahami dialektika kesadaran sebagai fenomenologi spirit Hegel, maka kita perlu memahami mengenai dialektika kesadaran antara majikan-pelayan. Kita selama ini salah kaprah bahwa dialektika kesadaran Hegelian sering disederhakan pada relasi tuan-budak. Padahal, budak dan pelayan berbeda dari maksud Hegel. Budak berkaitan dengan properti, sementara pelayan berkaitan dengan kerja. Kemerdekaan budak hanya terjadi melalui pemberontakan, sementara kemerdekaan pelayan terjadi karena bangkitnya kesadaran terhadap keberadaan dirinya. Sehingga, dalam hubungan kerja tidak bisa seorang majikan, pejabat, atau pemimpin memperbudak pelayan, bawahan, dan rakyatnya, karena mereka yang memperbudak orang lain sama dengan tidak bermoral, tidak berkarakter. Pada arti lebih luas, memperlakukan orang lain sebagai properti mengindikasikan bahwa keluarga, masyarakat, dan pemerintahnya sedang menciptakan kesadaran palsu bagi kehidupannya dengan merampas kesadaran manusia, karenanya menghancurkan tatanan spiritualitas manusia (Marcuse, 1941: 5657). Rose (1981: 56-57) memahami landasan sistem kehidupan etika dalam pemikiran Hegel bertolak belakang dari kehendak baik yang melandasi supremasi moral Kant. Hegal membalik pemikiran Kant, bukan kehendak baik yang mendasari absolutisme 
etika, melainkan kesadaran berbasis realitas dan keterbatasan identitas yang berbasis relasi sosial kepemilikan merupakan dasar kehidupan etika. Dalam konteks ini, kehidupan etika masyarakat mengacu pada akal teoritis dan praktik yang menjadi satu kesatuan. Akal teoritis adalah landasan formal atau konseptual berdasarkan kesadaran subjek 'melihat ke dalam' (seeing-into) objek, sementara itu praktik adalah rekognisi yang muncul dalam kenyataan relasi sosial. Keduanya bukan bergerak dalam kaidah dikotomis, melainkan progresif, saling berdialektis. Landasan formal tentang kehidupan etika bisa berasal dari pendidikan dan budaya, sedangkan praktiknya berasal dalam hubungan antar orang yang kongkrit. Ini bentuk representasi dan demontrasi dari spirit etis. Spirit berkorelasi dengan dunia kenyataan yang terdiri dari spirit subjektif (kesadaran diri yang individual) dan spirit objektif (kesadaran kolektif yang sosial) (Wood, 1990: 20). Dengan demikian, kebenaran dari spirit etis berdasarkan dialektika rekognisi yang menggerakkan kondisi kehidupan dan kematian, yakni kesadaran diri menuntut pengakuan martabat dari pihak lain, pihak lain bisa membatalkan atau merekonsialiasinya, tetapi pembuktian kesadaran diri ini harus mendapatkan konfirmasi sosial (Gadamer, 1976: 64-65).

Kesadaran sebagai pondasi subjek berkarakter bukan menjadi penentu utama tatanan moral. Moralitas merepresentasikan sistem kesalahan tentang kesadaran, perasaan, dan dunia kehidupan manusia. Empat sistem kesalahan moralitas ini berkaitan dengan ketidaklengkapan memahami diri kita, menganugrahi diri kita dengan atribut fiktif, menempatkan diri kita dalam keunggulannya dari alam atau mahluk lainnya, dan menciptakan skema pengetahuan baru atas sesuatu yang baik untuk menerimanya tanpa syarat (Nietzche, 1974: 115). Lahirnya moralitas bukan karena kesadaran diri terhadap dunia yang melandasi kenyataan atau kebenaran. Karena, dunia kehidupan manusia tidak pernah utuh, lengkap, dan stabil. Perspektif sebagai kehendak untuk mengetahui, kehendak akan kebenaran, sebagai cara menginterpretasikan dunia, hanya cerminan kesadaran mikroskopik yang berusaha menginspeksi dan membedah kenyataan yang sejatinya kita tidak mampu mengendalikan seluruhnya, sehingga ini lebih layak disebut sebagai realisme naif (Williams, 2001). Persoalan moralitas adalah persoalan kuasa. Persoalan kuasa berkaitan dengan perasaan berkuasa, yakni perasaan merasa diri lebih baik dibandingkan pihak lain yang segera memicu prasangka moral bahwa dirinya adalah jahat (evi) (Nietzche, 1997). Selain perasaan berkuasa ini, yang tidak kalah pentingnya adalah kehendak berkuasa. Perasaan berkuasa adalah efek dari kehendak berkuasa. Kehendak berkuasa adalah kemampuan afirmasi diri, kreasi, destruksi, dan revaluasi 
nilai-nilai. Revaluasi nilai-nilai sebagai gaya menafsirkan, suata gejala dari kondisi fisiologis dan tingkat spiritualitas tertentu secara umum yang berasal dari kita semua (Nietzche, 1968: 148). Kuasa ini tampaknya sinonim dengan agen yang punya insting kebebasan, sehingga ketika seseorang menerima kehendak berkuasa sebagai eksplanasi atau kebebasan argumentasi, maka dia harus menerima pengalaman refleksi diri, dan berusaha mengeskpresikannya, lalu bersedia dengan penilaian moral terhadap dirinya (Owen, 2007: 36). Hanya orang-orang yang memiliki kehendak yang lemah, tidak mampu memerintah dirinya, tidak berdaulat atas dirinya, sehingga institusi moral semakin berkembang pesat dan menyebar luas karena mereka butuh akan sandaran, implikasi dari lemahnya kehendak dirinya (Nietzche, 1974: 289).

Kehendak berkuasa ini berkontribusi bagi kebangkitan moralitas tuan-budak. Moralitas tuan-budak bukan berasal dari dialektika rekognitif, sebagaimana konsepsi Hegelian. Apabila kehendak berkuasa adalah dialektis, lalu mengapa muncul representasi moralitas tuan-budak ? Bukankah itu bentuk melampaui kenyatan atau kesadaran moral ? Representasi moralitas tuan-budak menyangkut lahirnya evaluasi moral. Bangsawan atau aristokrat merupakan kelas tuan. Kehendak berkuasa mereka adalah aktif: mencari tujuan hidup secara independen, langsung, dan terbuka. Di luar kalangan bangawan atau aristokrat adalah kelas budak. Kehendak berkuasa kelas budak adalah reaktif: mencari tujuan hidup atas pengaruh orang lain, tidak langsung, dan tertutup. Kehendak berkuasa tuan-budak yang melahirkan moralitas tuan-budak tidak mungkin dipahami sebagai dialektika rekognisi, yang satu mendominasi yang lainnya, agar mendapat pengakuan superioritas untuk mewakili kekuatan mereka, karena ini merupakan konsepi budak (Deleuze, 1986: 10). Rasa cemburu, iri, dan dengki yang dianggap buruk dalam moralitas tuan merupakan sesuatu hal yang baik dalam moralitas budak, karena mendorong keaktifan dalam bertindak, seperti seseorang yang merasa iri dan berusaha memperbaiki nasib hidupnya ketika melihat teman atau tetangganya yang sukses (Hunt, 1991: 49). Prinsip moralitas tuan adalah tentang baik dan buruk. Sementara, baik dan jahat adalah prinsip moralitas budak. Kesenangan, keberanian, keindahan, kebahagiaan, dan kepasitas diri menjaga jarak dari ketidakberdayaan dianggap kekuatan baik bagi moralitas tuan, sebaliknya kelemahan, pengecut, rendah hati, dan ketergantungan yang tinggi dianggap buruk. Tetapi, apa yang dianggap buruk bagi moralitas tuan dianggap baik bagi moralitas budak. Sebaliknya, apa yang dianggap buruk bagi moralitas tuan dianggap jahat bagi moralitas budak, sebab berhubungan dengan 'dosa'. Kebencian budak terhadap moralitas tuan melahirkan revolusi moral. Meskipun kelas tuan mengafirmasi dirinya, 
"Ya, pada hidupnya", tidak ada kompensasi bagi kelas budak terhadap moralitas mereka. Kelas budak menganggap “Tidak, pada kekuatan di luar dirinya” sebagai afirmasi kekuatan kreatif mereka, karena membalikkan nilai-nilai moralitas tuan, moralitas kelas bangsawan (Nietzche, 1989; Hatab, 2008).

Serangan terhadap filsafat moral datang dari Sosiologi. Menurut Durkheim (1953: 19), realitas moral tidak bisa didefinisikan atau dikonseptualisasikan dari pertanyaan filosofis yang 'mengawang-ngawang', bekerja di belakang meja. Sosiologi sudah waktunya meninggalkan cara berpikir filosofis ketika mengkaji realitas moral. Sosiologi harus berdiri independen dari filsafat, karena pondasi Sosiologi dibangun berdasarkan fakta sosial, studi empiris kehidupan masyarakat, dan bukan kajian metafisis yang sulit diterapkan pada fenomena sosial (Durkheim, 1982: 159). Sosiologi harus mengeksplorasi dan menjelaskan berbagai kekuatan sosial yang berasal dari ikatan emosional kolektif sebagai cita-cita moral (Collins, 1975). Solidaritas sosial ini terpelihara melalui ritual-ritual masyarakat atau komunitas bagi keberlangsungnya tatanan realitas moral (Durkheim, 1954). Dengan demikian, kewajiban moral dan kehendak moralitas bermula ketika individu menjadi anggota masyarakat atau komunitas, sehingga kualifikasi dan konstitusi moral masyarakat atau kelompoknya memaksa serta menekan secara eksternal bagi individu. Segala penyimpangan akan mengganggu stabilitas moral, tertib sosial, dan berujung gangguan (anomie) keseluruhan sistem kehidupan masyarakat. Karena itulah, ada konsekuensi moral bagi setiap individu. Konsekuensi moral ini terdiri dari dua bentuk menurut Durkheim. Pertama, mekanisme dari berbagai pelanggaran. Orang yang melanggar konsensu umum aturan kebersihan atau kesehatan, misalnya, secara otomatis akan berakibat munculnya penyakit pada dirinya. Kedua, sangsi bagi pelanggaran. Orang yang melakukan pembunuhan, misalnya, tidak bisa dianalisa dalam segi apa pun, karena itu pelakunya harus mendapat hukuman, baik secara otoritas institusional maupun sosial. Dengan demikian, upaya penanaman moral melalui sektor pendidikan sangat diperlukan, terutama dalam masyarakat perkotaan atau modern, karena pada masyarakat ini solidaritas sosialnya lebih lemah dibandingkan solidaritas masyarakat pedesaan. Bellah (1973) dalam pengantar karya Durkheim, "Moralitas dan Masyarakat", menjelaskan bahwa terdapat tiga elemen dasar moralitas yang diperlukan dalam dunia pendidikan. Pertama, kedisiplinan sebagai pengontrolan ego individu dan penguatan kewajiban moral. Kedua, ikatan kelompok sosial yang membuat antar individu merasakan kehangatan (bagian dari keluarga), sehingga membuatnya tertarik dan terikat tanpa merasakan adanya paksaan dari luar dirinya. Ketiga, otonomi moral atau 
penentuan nasib sendiri yang pada konteks ini moral harus rasional, seperti aturan hukum yang memberikan rasa keadilan, sehingga kebebasan bagi setiap individu dibatasi olehnya, sekalipun aturan itu bisa diperbarui secara rasional demi menjaga keteraturan di antara intelektualitas individu yang terus berkembang. Ritus-ritus peralihan juga tidak kalah pentingnya bagi moralitas kolektif. Seperti, seremoni sosial, pernikahan, kelahiran, kematian, kalender keagamaan, hingga ritual antisipasi kedaruratan termasuk contoh ritus-ritus peralihan yang bisa memperkuat sentimen emosional kolektif dan merevitalisasi kendornya moral sosial (Collins, 2009). Oleh karena itu, program sentral pemikiran Durkheim adalah sosiologi moral yang memberi penekanan pada solidaritas sosial, kesadaran kolektif, anomie, obligasi umum yang berlaku bagi setiap orang, dan moralitas kelompok sosial yang mendorong partisipasi bagi anggotanya dalam institusi atau organisasi kemasyarakatan (Turner, 1992; Turner, 1993).

Namun, pemikiran Durkheim mengenai sosiologi tidak selalu mendapatkan persetujuan semua pihak. Collins (2009) menyebutkan setidaknya di komunitas sosiolog ada dua keberatan mendasar terhadapnya. Pertama, di tangan Durkheim, studi moral sosial menjadi disiplin ilmu formal, karena hukum-hukum tatanan sosial yang melebihi kapasitas individu menjadi hukum generalisasi dan bebas nilai. Pandangan idealisme moralnya mengandaikan tidak adanya suatu krisis di masyarakat. Padahal, terdapat perbedaan otoritas kelompok status maupun kelompok berkuasa (partai) di masyarakat. Weber (1978: 215-216) mengklasifikasikan tiga jenis otoritas: rasionalitas formal, tradisional, dan kharismatik. Otoritas yang berasal dari jabatan seseorang dalam rantai struktur birokratik disebut otoritas rasionalitas formal. Otoritas tradisional berasal dari kepala suku atau tokoh masyarakat berdasarkan budaya dan tradisi masyarakat setempat. Otoritas kharismatik berasal dari 'anugrah' personal, seperti kepahlawanan, keteladan, maupun kewahyuan. Ketiga otoritas ini memberi persetujuan bagi setiap individu dalam kapasitasnya menciptakan tindakan bermakna bagi orang lain yang berada pada wilayah otoritas kelompok status (etnis, pendidikan, agama, dan sebagainya) dan kelompok berkuasa (pekerjaan atau mata pencaharian, bidang pemerintahan, partai, dan sebagainya) dalam kerangka tindakan moralitas yang satu dengan lainnya sangat mungkin saling bertentangan. Kedua, kehidupan masyarakat sangat sulit diprediksi, selain perbedaan historis, juga karena kemampuan interpretasi masing-masing individu. Bagi Weber (1992), kebebasan merupakan pijakan dasar memahami aktivitas manusia. Weber memberikan argumentasi tentang hal ini bahwa sejarah manusia perlu dilihat dalam kaitannya antara ide dan aktivitas material 
sebagaimana ajaran Protestan. Melalui etika Calvinisme setiap manusia 'terpanggil' (The Calling Man) untuk melakukan tugasnya masing-masing di muka bumi. Konsep 'terpanggil' ini mungkin sinonim dengan eksistensi, atau dalam pandangan Islam 'yang dirahmati'. 'Keterpanggilan' ini berhubungan dengan pemahamannya terhadap kepercayaan dan aktivitas ekonomi yang kemudian dikenal dengan spirit kapitalisme. Ajaran Calvinisme cenderung memberikan kebebasan dan kenikmatan spiritual, tanpa tekanan yang sangat kuat dari institusi agamanya. Namun, tindakan kebebasan mereka punya tanggung jawab sebagai instrumen evaluasi Tuhan, bukan kepada institusi manusia. Mereka bebas untuk bersenang-senang atau bermalas-malasan sehingga memikul dosa besar, atau semangat bekerja di dunia yang tidak tergoda memperkaya diri sendiri, melainkan juga ikut membantu orang lain yang kesulitan ekonomi sehingga mendapatkan evaluasi positif dari Tuhan. Tindakan rasional ini berbasis dari sejarah ide tentang 'keterpanggilan' di dunia sebagai kebajikan dan nilai-nilai keselamatan hidup (Giddens, 1971: 129-130). Interpretasi moral dan imbasnya pada aktivitas ekonomi ini bukan satu-satunya berasal dari ajaran Calvinisme atau Protestan. Karena, dalam ajaran Islam juga demikian. Weber mungkin mengabaikan 'agama individu' dalam umat Islam karena dominasi kelompok syariat Islam, sehingga ajaran Islam ini dianggap membatasi atau mengeliminasi kemajuan aktivitas perekonomian, meskipun sesungguhnya aktivitas duniawi atau material menurut ajaran Islam harus bersendikan pada keadilan dan kesetaraan, agar tidak membuatnya terlena oleh kemegahan material yang menghambat jalan menuju pintu surga atau melemparnya ke neraka (Turner, 1974: 13). Dengan demikian, berdasarkan ajaran Islam bahwa 'keterpanggilan' manusia dengan daya rasionalitasnya harus dilengkapi pula dengan kapasitas mereka belajar 'membaca' dunia kehidupan, baik yang material maupun non material, sebagai bagian dari keimanan (Gellner, 1981).

Pertanyaannya kemudian bagaimanakah karakter orang Madura dalam konteks korona, sehingga karakter orang Madura ini berkontribusi bagi dunia kehidupan mereka yang mungkin saja tidak lagi sama pasca korona ? Inilah persoalan yang hendak dijawab sebagai tujuan utama tulisan ini. Ada beberapa kesulitan dalam menunjukkan secara presisi mengenai karakter orang Madura, terutama ketika bangsa ini, tanpa diprediksi, bisa terserang dan terpapar virus korona. Tulisan mendalam tentang tematema karakter orang Madura selama ini rupanya ditulis belum tersistematis di kalangan kesarjanaan atau kelompok akademisi Madura, apalagi karakter orang Madura yang berguna menghadapi atau mengatasi pandemi korona yang baru saja terjadi dan sulit diprediksi kapan akan terhenti. Sekalipun demikian, perlu sedikit mengulas karakter 
orang Madura yang telah tersaji singkat atau ditulis sporadis oleh pemerhati atau kelompok akademisi Madura.

Pembahasan karakter orang Madura sering muncul dalam kongres kebudayaan Madura. Tetapi, tulisan tentang karakter orang Madura ini cenderung bukan hasil penelitian mendalam, karena sekedar hasil pengamatan sepintas sebagai pengingat bahwa orang Madura semestinya memahami karakter mereka dari sudut pandangan serta pengalaman hidupnya sendiri. Karakter kekerasan adalah tema paling sering dibicarakan dalam kongres kebudayaan Madura, baik jilid perdana (dihelat di Sumenep, pada 8-11 Maret 2007) maupun kedua (juga digelar di Sumenep, pada 21-23 Desember 2012). Pada kongres kebudayaan Madura perdanananya, Wiyata (2007) menulis bahwa karakter orang Madura yang paling sering diingat orang luar Madura sepertinya tidak pernah ke luar dari karakter kekerasan. Padahal, bagi orang Madura makna "keras" dan "tegas" itu berbeda. Keras berhubungan dengan kondisi eksternal, seperti sifat alam yang tidak mungkin dijinakkan seluruhnya oleh manusia Madura. Maka, orang Madura senantiasa bekerja keras supaya bertahan hidup dalam kondisi alam yang tidak menentu. Tegas berbeda dari keras karena menunjukkan prinsip hidup mereka yang tidak mudah terombang-ambing oleh godaan dari luar dirinya. Setiawan (2007) berpendapat bahwa karakter keras orang Madura tidak bisa dilepaskan dari sejarah keberanian orang Madura dalam mempertahankan tanah airnya, tetapi hampir selalu dimanfaatkan oleh kaum penjajah untuk memerangi bangsanya sendiri yang pada umumnya berasal dari luar Madura. Ketua dewan pendidikan Sampang, Bey (2012), mencoba menyajikan kembali karakter orang Madura yang nyaris hilang karena terseret arus globalisasi. Meskipun upayanya menemukan kembali karakter orang Madura yang nyaris hilang ini hanya sebatas retorika penguasa tanpa disertai kekayaan data pendukung yang memadai, paling tidak gagasannya ibarat menabuh lonceng peringatan kepada generasi mudanya betapa pentingnya merawat karakter orang Madura yang dianggap memudar oleh perkembangan zaman. Karena itu, muncul proyek penulisan penguatan pendidikan karakter dari kementerian pendidikan dan kebudayaan tahun 2017, dan salah satu hasilnya adalah terbitnya modul pelajaran yang ditulis oleh orang Madura, Sulaiman Sadik. Menurut Sadik (2017) karakter orang Madura secara garis besar mengacu pada tiga hal: peduli lingkungan, berbahasa Madura dalam keluarga, dan Islam. Seperti gagasan karakter orang Madura yang ditulis oleh penulis sebelumnya, karakter orang Madura dalam modul penguatan pendidikan karakter ini terkesan mendiskualifikasi kebebasan kreativitas individu orang Madura. Karakter orang Madura yang memberi pandangan konsepsi subjektivitas orang Madura 
datang dari Rifai (2007). Berdasarkan ekspresi kebahasaan sehari-hari orang Madura, dia menunjukkan bahwa karakter orang Madura yang individual bisa dilihat dari istilah èjhin (keperseorangan). Karakter èjhin ini bisa setidaknya berurusan dengan makna kekeluargaan dan kemandirian. Misalnya, pemahaman tentang jarak sosial ikatan kekeluargaan terlihat dari peribahasa satèndhâ', sapècca' (selangkah, sekaki), yakni kuat tidaknya hubungan emosional di antara silsilah keluarga sedarah. Maka, di antara orang Madura konsep keluarga bisa terpancar dari 'dalam ke luar' atau 'dari luar ke dalam'. Sesama saudara (trètan) bisa tidak dekat karena perselisihan atau kurangnya kepedulian, sebaliknya sesama teman (kancah) bisa seperti saudara karena kedua belah pihak saling memahami dan memiliki rasa kepedulian yang tinggi. Karakter èjhin ini juga bisa tampil dalam urusan kebaikan sosial yang berdampak nyata bagi orang sekitar (kabhâghusen). Orang Madura bukan tipikal manusia yang suka membuangbuang waktu hanya untuk menunggu belas kasihan struktural dan institusional yang berjenjang. Spontanitasnya dan kemandiriannya untuk mempermudah segala urusan orang lain terkadang melebihi kegotong-royongan. Contohnya, upaya orang Madura mendirikan surau (langghâr), musholla kampung, atau masjid desa yang dananya dari kantong pribadi atau patungan sesama teman, tanpa menunggu bantuan dari pemerintah yang rumit (maruwet) dan berliku-liku (a lè'-palè').

Walaupun demikian, berbagai ulasan tentang karakter orang Madura di atas sepertinya belum menampakkan wujudnya secara terang benderang dalam menghadapi atau mengatasi situasi krisis, seperti situasi pandemi yang sedang menimpa seluruh negeri ini sepanjang tahun 2020-2021, termasuk Madura. Pada situasi krisis ini biasanya dicirikan oleh tindakan persekusi atau aksi mobilisasi penganiayaan, langsung maupun tak langsung, bagi pihak lain yang layak dijadikan 'tersangka'. Girard (1986) menjelaskan bahwa persekusi kolektif sebagai ciri suatu krisis di masyarakat terjadi karena stereotip budaya, seperti penyingkiran kelompok sosial yang dianggap tidak berdaya atau lemah, gangguan politik, dan konflik agama yang muncul akibat lemahnya atau gagalnya institusi normal mengintegrasikan pluralitas masyarakat, serta teror politik sebagai imbas resiprokal negatif, seperti opini publik, yang menimbulkan permusuhan di antara dua kubu yang berbeda perspektif. Pada situasi krisis moral, karakter persekutor lebih mudah mengkambinghitamkan pihak lain daripada diri sendiri, seperti keseluruhan masyarakat maupun kelompok sosial tertentu yang dianggap telah merugikan atau menyebabkan hilangnya diferensiasi budaya, sehingga sangat diperlukan penyeragaman normalisasi kehidupan, kendati uniformitas budaya ini kontradiktif dan membingungkan masyarakat. Ketika situasi krisis 
ini mulai meresahkan masyarakat, maka karakter pengorbanan menjadi jalan keluarnya, tujuannya memulihkan stabilitas tatanan harmoni dan mengatasi kepanikan moral.

Menurut Girard (1977) karakter pengorbanan merupakan kesalahpahaman cara berpikir yang bersumber dari tindakan pengorbanan substitusional dan balas dendam, baik terlegitimasi maupun tidak, publik maupun privat. Pengorbanan substitusional merupakan kesadaran dan praktik mentransposisi atau mentransfer dari korban (objek yang tersingkir) berganti berkorban (subjek yang terkontingensional) untuk memproteksi masyarakat keseluruhan dari malapetaka berkepanjangan. Sosok raja atau penguasa yang sebenarnya menjadi pusat pengorbanan bagi masyarakat tampaknya melarikan diri karena mengisolasi dirinya dari jeritan dan kritik sosial. Maka, individu berusaha mendapatkan kembali kebebasannya dengan 'balas dendam' sebagai cara menunjukkan keterbatasan struktur sosial menjaga anggotanya dari krisis, suatu tindakan kekerasan atau pengasingan 'orang luar' tanpa risiko balas dendam. Krisis moral dari struktur sosial hegemonik seperti ini menyebabkan krisis konsensus sehingga aksi koersif lebih banyak digunakan supaya fenomena 'pencurian' ('mugging') yang menggerogoti legitimasi politik dan kultural bisa dipulihkan kembali, atau bisa juga menggunakan kontrol mental melalui praktik reinterpretasi dan representasi realitas sosial (Hall, dkk., 1978: 218-219). Situasi krisis tidak selalu menciptakan tindakan kesalahanpahaman seperti karakter pengorbanan. Melainkan juga, menumbuhkan kemampuan refleksi dan kritik sebagai karakter krisis. Menurut Husserl (1965) bahwa refleksi berhubungan kesadaran atau menyadari sesuatu, dan kritik berhubungan dengan cara mempertanyakan klaim atau legitimasi kebenaran, bukan tentang "ya atau tidak", sesuai disiplin ilmu "ini atau itu", melainkan tentang kebermaknaan bagi diri kita sendiri. Sehingga, dunia kehidupan melibatkan praktik dan keingintahuan alamiah dari individu, berdasarkan ruang lingkup di mana mereka tinggal, dalam arti lain, sekalipun di lingkungan mereka tinggal terdapat horizon natural (keluarga, komunitas, agama, dan lainnya) tidak mampu menghalangi kesadaran yang tidak terbatas dari individu untuk memahami dan menjelaskan dunia kehidupan melalui tindakan mengetahui dan menginvestigasi sebagai bagian dari keterikatannya dengan kesadaran diri yang mengkreasikan makna. Di sini, terdapat responsibilitas yang tidak datang dari luar, melainkan dari dalam dirinya, untuk mengklaim kebenarannya atas dasar seberapa pentingkah baginya, apakah menyuarakan dirinya, atau justru sebaliknya, mengekslusi dirinya dari ketertarikannya pada penciptaan makna hidupnya (Dodd, 2004). 


\section{METODE}

Kegagalan memahami karakter sosial suatu masyarakat bukan karena maksim absolut yang sering kita dengar, seperti "ikuti saja aturannya, hidupmu akan tenang", "lakukanlah yang benar", dan lainnya, melainkan karakter sosial seringkali dijelaskan dari metode penelitian ilmu alam, sehingga, terjadilah dilema moral, moral cenderung normatif, karena minimnya otonomi individu dalam mempertimbangkan tingkah laku, kepercayaan, dan nilai-nilai (Hunter, 2000: 146-147). Karekter sosial meniscayakan bahwa tidak ada seorang pun yang bisa hidup sendiri, sehingga mode konformitas atau kreatifitas mengacu pada 'direksi eksternal' ('petunjuk dari luar' dirinya) (Riesman, 1961), tetapi asumsi seperti ini hanya menempatkan manusia tak lebih dari atomisasi, bahan baku ilmu fisika atau kimia, karenanya ilmu sosial jatuh pada absurditas, sehingga karakter sosial sebaiknya memberi tempat terbaik bagi keberadaan manusia sebagai alat memahami hubungan sosial supaya lapangan penelitian tentang hidup mereka menciptakan wirausahawan makna, memperhitungkan pemahaman kehidupannya, berdasarkan metode ilmu sosial, terutama sosiologi, yang akarnya bertumbuh dari fenomenologi eksistensial (Lyman dan Scott, 1989). Husserl sebagai 'bapak' fenomenologi mengistilahkannya sebagai fenomenologi genetik yang berpusat pada dunia kehidupan, yakni refleksi subjek yang menghasilkan makna sebagaimana yang biasa dilakukan para filsuf, tetapi makna bukan berasal dari 'arti kata' atau tindak berbicara, melainkan dari pengalaman yang bisa 'dijangkau', 'ditangani', atau 'dijalani', sehingga aktivitas hidup menjadi 'relevan' (Dodd, 2004: 16-17).

Fenomenologi Husserl juga sering dikenal sebagai fenomenologi pengetahuan karena metodenya berusaha mempersoalkan pengetahuan, dan dia mendefinisikannya sebagai 'ilmu' fenomena yang murni. Problem pengetahuan tersebut terdiri dari dua aspek. Pertama, persoalan transendental yang mempertanyakan tentang bagaimanakah kesadaran melampaui dirinya dan membuat kontak dengan objek di luar dirinya. Kedua, problem pengetahuan yang terlibat pada persoalan korespondensi mengenai bagaimanakah kita bisa menyetujui dan meyakini adanya korelasi tindakan mengetahui dan objek yang diketahui (Husserl, 1999). Yang pertama terkait tentang kesadaran, sedangkan yang kedua tentang esensial atau imanen. Komponen tindakan mengetahui ini dalam istilah Husserl sebagai sesuatu yang riil ("noetik"), yakni sesuatu di luar diri kita menampakkan diri ke dalam pikiran, memori, atau imajinasi kita, dan intensionalitas ("noematik"), yakni ketercurahan atau tindakan referensial terhadap objeknya, sekalipun tidak menampakkan dirinya. Karena itu, fenomenologi secara esensinya merupakan tindakan mental yang disusun berdasarkan kesadaran yang 
kongkrit atau pengalaman bermakna bagi individu dan diarahkan pada presensi objek eksternalnya (binatang, orang, benda, dan lain sebagainya), serta persepsi internal berdasarkan pengalaman aktual yang berelasi dengan 'pemberian' objek, sehingga ia dapat dipahami sesuai representasi objeknya, dan menjadikannya data diri sebagai pondasi fenomenologi yang murni (Husserl, 2001: 202-205). Prosedur fenomenologi Husserl ini berupa 'memberi tanda kurung' atau menangguhkan berbagai penilaian saintifik (epoche). 'Memberi tanda kurung' ini bukan sebatas sikap hormat pada duniakesadaran, melainkan juga menginvestigasi asal mula konstitusi, kapabilitas melihat 'penampakan' dan mensistematiskan investigasi tentang bagaimana karakateristik 'kebiasaan diterima' (Husserl, 1970: 263). Maka, lapangan riset fenomenologi Husserl ini bukanlah berkonsentrasi pada pikiran privat yang sulit diintrospeksi, melainkan intersubjektivitas yang bisa diakses mode 'penampakan' berdasarkan praktik menginvestigasi dan mengeksplorasi subjek transendental yang korelasi konstitusi pada dunianya dapat divalidasi dari subjek yang lainnya (Zahavi, 2003: 54).

\section{HASIL DAN PEMBAHASAN}

Eksistensi pandemi korona di Madura boleh terbilang sangat 'terbelakang', setidaknya informasi merebaknya korona di Madura yang muncul di media massa dimulai setelah setahun pandemi ini berjalan, atau berbarengan dengan tersebarnya informasi kemunculan varian baru Covid-19 di Kudus dan Jakarta. Varian korona baru juga meledak di Bangkalan, Madura Barat, dan terdeteksi pada awal Juni 2021, setelah adanya lonjakan kasus dari 12 menjadi 322 kasus dalam sehari, hingga pasien baru yang datang ke rumah sakit daerahnya tidak tertampung lagi dan harus merujuk ke rumah sakit di Surabaya. Pengisolasian pulau Madura segera dilakukan oleh pemerintah daerah agar mengantisipasi menyebarkan varian baru korona, sekalipun pada akhirnya pengisolasian yang berkepanjangan ini menyulut gerakan protes dari anak-anak muda Madura, karena kebijakan darurat pandemi di Madura dianggap diskriminatif (Raditya, 24 Juni 2021). Krisis sosial yang disebabkan situasi pandemi seperti ini bukan hal baru dalam sejarah hidup orang Madura. Madura pernah mengalami pandemi lepra atau kusta sejak pertengahan abad ke-17. Berdasarkan catatan Encyclopaedie Van Nederlandsch Indie (1918), penyakit lepra ini pada mulanya menyebar dari tahanan perang yang dibawa rezim Hindia-Belanda ke Batavia dari berbagai daerah yang sebelumnya dijajah bangsa Portugis. Perhitungan kasar Dort (1898) bahwa Madura Barat, Sampang (248 kasus) dan Bangkalan (431 kasus) termasuk daerah yang angkanya paling tinggi dibandingkan Pamekasan (117 kasus) 
dalam persoalan pandemi lepra. Mandangin sebagai pulau terluar daerah Sampang kala itu dipercaya, setidaknya mengacu pada cerita tuturan turun-temurun dari orang tua kepada anak cucunya, sebagai wilayah pengasingan para penderita lepra (dhâghing bucco'). Jika di masa pandemi korona setiap orang diharuskan memakai masker sebagai salah satu cara meminimalisir penyeberannya, maka di masa pandemi lepra di Madura setiap orang yang hendak bertemu dengan penderita lepra diwajibkan menutup seluruh badannya, kecuali kedua matanya, sehingga mirip dengan pakaian yang dikenakan oleh algojo hukuman cambuk di Aceh. Pada pandemi lepra ini, orang Madura tidak hanya menjadi pencuriga tentang asal-usul seseorang sebagai keturunan keluarga lepra atau tidak, melainkan juga melarang anak-anak Madura untuk menjalin asmara dengan keturunan mereka. Sekalipun penyakit lepra bisa disembuhkan secara medis di masa sekarang, sebagian orang Madura masih was-was, sehingga menjaga jarak sosial dan kultural dengan keluarga lepra, karena pandemi lepra baginya bukan masalah medis, melainkan problem teologis (kutukan) atau mistik. Tetapi, karakter alienatif ini tampak berbeda dengan situasi pandemi korona yang memunculkan atau membangkitkan penguatan karakter krisis yang mungkin saja bermanfaat bagi dunia kehidupan orang Madura di masa mendatang, ketika mereka mengalami peristiwa krisis serupa atau yang sedikit berbeda. Terdapat lima karakter krisis orang Madura pada situasi pandemi korona yang hingga kini, (ketika tulisan ini sedang dibuat), drama kepahitan hidup dicengkram badai korona masih menghantui kehidupan sehari-hari orang Madura.

\section{Pènal}

Pènal atau lalongèdhân (lalongitan) merupakan istilah khas orang Madura yang identik dengan kepiawaian menemukan jalan keluar dari segala macam kesulitan hidup, teknis maupun non teknis, yang bagi orang lainnya persoalan itu dianggap sesuatu beban dan selalu berakhir dengan jalan buntu. Secara teknis, kepènalan ini berurusan dengan peralatan atau perbendaan. Sementara, secara non teknis, kepènalan berurusan dengan segala hal di luar perbendaan atau peralatan, terutama dalam hal kerelaannya membantu orang lain yang menghadapi kesusahan. Misalnya, alat perekat yang digunakan oleh orang Madura. Untuk menempelkan perangko atau materai dibutuhkan alat perekap seperti lem. Tetapi, tidak semua orang Madura memilikinya. Supaya, perangko atau materai bisa segera ditempel dalam suatu dokumen, maka orang Madura akan menggunakan satu butir nasi sebagai alat perekatnya. Sehingga, dokumen penting tersebut bisa sesegera mungkin dikirimkan kepada orang lain yang memintanya. Inisiatif, kreativitas, atau spontanitasnya menggunakan sebutir nasi ini 
sebagai alat perekat adalah contoh kepènalan teknis, sedangkan kebutuhan untuk memudahkan pekerjaan orang lain menerima dokumennya tanpa terhambat karena tidak adanya alat perekat merupakan contoh kepènalan non teknis atau sosial. Kategori alat perekat lain, di luar perekat dokumen ini, berhubungan dengan pelengkap makanan khas orang Madura, misalnya, rujak. Rujak yang terdiri keripik singkong, kecambah, sayuran, tahu, cingur sapi, cabai, dan kacang tidak akan terikat satu dengan lainnya dalam satu paduan rasa tanpa adanya petis sebagai perekat semua bahannya. Petis Madura ini diperkirakan sudah ada jauh sebelum Indonesia merdeka. Bahan dasar petis berasal dari ikan laut, biasanya tongkol, pindang, atau udang yang diambil sari patinya, lalu diracik sedemikian rupa sehingga jadilah petis Madura.

Berdasarkan penuturan orang tua Madura, konon memakan petis berlebihan diyakini menjadi penyebab Ragapadmi terkena penyakit kulit, sehingga kulitnya yang kuning langsat menjadi lebam-lebam dan sedikit melepuh. Ragapadmi dalam sejarah Madura dikenal sebagai putri raja Pacangan yang pada masa invasi besar-besaran kerajaan Mataran ke pulau Madura, pada tahun 1600-an, raja Pacangan juga ikut bertempur. Orang-orang Mandangin yang punya sejarah dengan Ragapadmi ini, hingga kini, terkenal sebagai penggemar petis Madura, bahkan hidangan makan sehari-hari terasa belum lengkap tanpa kehadiran petis di meja makan mereka. Petis Madura bagi mereka bukan sebatas makanan pelengkap, melainkan juga bergeser sebagai menu utama sebagai penghemat pengeluaran atau menghadapi situasi paceklik pangan. “Mon ta' negghu' pèssè, makkè ngakan pettès pagghun kobâssah”. (Tatkala sedang tidak punya uang, makan dengan bumbu petis akan terasa nikmat). Ungkapan seperti ini bukan sesuatu yang asing di telinga orang Madura. Informasi lainnya mengatakan bahwa petis Madura bukan berasal dari satu wilayah Madura saja. Karena, petis Madura adalah pelengkap hidangan keseharian orang-orang yang tinggal di wilayah pesisir pantai. Sehingga, mereka berusaha menemukan racikan menu makanan baru yang diolah dari tangkapan hasil melaut, petis Madura contohnya. Karena proses perdagangan dan ikatan sosial di antara orang Madura, maka petis Madura yang semula berasal dari masyarakat pesisir pantai perlahan menyebar ke penjuru perkotaan Madura, hingga merambah juga ke luar pulaunya. Hampir setiap rumah orang Madura akan ditemukan petis di dapur atau lemari makan mereka. Anak-anak muda Madura menggunakan petis sebagai media perekat pertemanan mereka. Hampir setiap akhir pekan atau memasuki liburan sekolah, mereka melakukan temu akrab ('temmo kerrong') sesama teman sebayanya untuk mengadakan pesta rujak. Sewaktu musim panen mangga, apalagi memasuki bulan puasa hingga lebaran tiba, petis sering diburu 
untuk memenuhi bahan penikmat santapan mereka. Pada masa pandemi korona, petis menjadi salah satu cara menjaga jarak alamiah di antara orang Madura. Orang yang terlalu sering mengkonsumsi petis akan membuat keringatnya berbau kecut, dibandingkan orang yang sering mengkonsumsi kemangi. Dengan kecutnya keringat, maka orang-orang di sekitar secara spontan akan menjauhkan diri darinya. Sehingga, orang Madura merasa tidak perlu keseringan memakai masker, karena petis Madura bisa dimanfaatkan pengganti masker yang efektif dan mujarab. Bukan hanya perubahan bau keringat, petis Madura yang diolah dari saripati ikan laut ini memiliki kandungan gizi yang berguna bagi imunitas tubuh. Dengan begitu, petis Madura bermakna jamak: kebutuhan pangan, kesejahteraan keluarga, perdagangan, keintiman sosial, dan alat anti virus korona. Melalui petis Madura ini kita setidaknya mengenal kepènalan orang Madura dalam aspek pengolahan makanan khas orang Madura yang boleh jadi sangat jarang ditemukan di daerah lain yang belum bersentuhan dengan kehidupan orang Madura.

Orang Madura pada umumnya tidak percaya dengan korona sebagai penyakit atau virus mematikan yang hanya bisa diobati dengan perspektif medis. Bagi mereka, datangnya korona satu paket dengan penyakit mistis, yakni pencarian tumbal para dukun santet yang menebarkan sihir wabah mematikan. Orang Madura menyebut sihir ini dengan wabah "tok-tok-tok" (bunyi ketukan pintu yang mematikan) atau di luar Madura dikenal sebagai penyakit to'un. Penyakit ini mengingatkan kita terhadap peristiwa kejatuhan rezim orde baru yang diikuti dengan krisis moneter dan merebaknya isu dukun santet. Peristiwa dukun santet ini menyulut kewaspadaan tingkat tinggi di Madura. Orang Madura membatasi diri ke luar rumah di malam hari. Apabila, terpaksa ke luar rumah di malam hari karena kepentingan yang sangat mendesak, maka mereka harus didampingi oleh keluarga, kerabat, atau teman dekat. Di wilayah pedalaman dan sekitar pinggir pantai Madura, korona masih kalah mematikan dibandingkan wabah "tok-tok-tok" ini. Hinggapnya wabah ini biasanya terjadi di malam hari. Dimulai dari bunyi ketukan pintu rumah yang tuan rumahnya tidak pernah melihat siapa tamu yang mengetuk pintu itu. Di daerah utara Madura, antara batas Bangkalan-SampangPamekasan, rumor mengenai wabah mistik ini telah terdengar kencang, menyebar dari mulut ke mulut (caca ka caca), sehingga tampak lebih nyata kehadirannya dibandingkan statistik penyebaran virus korona. Kabarnya, sudah banyak korban berjatuhan terpapar wabah mistik ini karena mereka penasaran untuk membukakan pintu rumah yang diketuk oleh tamu tak diundang itu. 
Begitu pintu rumahnya dibuka, tiba-tiba angin kencang menerjang tubuhnya, membuat pemilik rumah kejang-kejang, seakan kesurupan, dan dalam beberapa hari ke depan dia tinggal menunggu ajal datang. Sehingga, yang perlu ditangkal mereka bukan virus korona, melainkan wabah sihir to'un ini. Apabila wabah mistik ini bisa diatasinya, maka korona juga akan lebih mudah terkendali di Madura. Orang Madura yang percaya pada pandemi mistik atau sihir ini tidak berharap bantuan petugas medis untuk mengatasinya, melainkan pergi mendatangi dukun 'putih' (dhukon potè) atau seorang kiai yang dianggap memiliki ilmu sakti. Mereka yang telah menemui para penangkal wabah ini disarankan membuat ketupat, layaknya ketupat yang dibuat sewaktu merayakan lebaraan Idul Fitri. Ketupat ini kemudian digantung di depan pintu mereka, agar mahluk gaib itu tidak berani lagi mengetuk pintu rumahnya. Berdasarkan penuturan dukun 'putih' itu, setiap malam hari pintu rumah harus dipalangi di sisi dalamnya dengan sebuah sapu. Berbeda dari jalan keluar dukun 'putih', kiai sakti memobilisasi warga desa untuk melakukan gerakan membaca barjanzi atau sholawat nabi keliling desa setiap malam hari, biasanya selepas sholat Isya'. Puasa senin-kamis juga menjadi gerakan lainnya, supaya wabah sihir itu tidak bisa masuk ke tubuh orang berpuasa. Gerakan anti pandemi mistik ini punya efek domino mengatasi serangan korona. Dengan berpuasa, mereka akan membatasi diri bergaul dengan banyak orang, agar mereduksi perbuatan tercela yang bisa mengurangi bobot pahala dan membatalkan puasa, misalnya bergosip, menghina, memfitnah, sombong, atau tidak mampu mengendalikan emosi dengan lawan bicaranya. Kepènalan orang Madura seperti ini jarang ditemukan pada kondisi hidup normal dan stabil atau tidak sedang mengalami situasi krisis atau kedaruratan.

\section{Mertèh}

Sebelum meluasnya berbagai industri otomotif seperti sekarang, alat transportasi utama orang Madura adalah kaki. Orang Madura sudah terbiasa berjalan kaki di masa lalu dari daerah ke daerah lain untuk berbagai urusan, mulai dari mengunjungi kerabat, bersekolah, berdagang dan membeli kebutuhan dasar di pasar, berziarah, hingga pergi berperang di garis depan. Sosok Jokotole tergolong salah satu sejarah termasyur bagi orang Madura karena berhasil mendirikan pintu gerbang pertahanan kerajaan Majapahit. Jokotole menjadi raja di Sumenep selama empat puluh lima tahun, dari tahun 1415 hingga 1460. Sejak kecil, Jokotole telah terpisah dari orang tuanya. Dia diasuh oleh seorang pandai besi yang berada jauh dari pusat istana, tempat keluarga Jokotole berasal. Semasa mudanya, dia pergi menuju pusat kerajaan Majapahit yang berada di daerah Mojokerto dengan berjalan kaki, menelusuri hutan belantara 
sepanjang Madura hingga menuju ke tempat tujuannya. Dia hendak membantu ayah angkatnya yang tidak kunjung pulang karena pintu gerbang kerajaan belum berhasil tegak berdiri akibat kesulitan alat perekat yang kuat. Dengan kesaktiannya yang diturunkan dari keluarga besarnya yang suka bertapa, menjauh dari hiruk pikuknya istana dan mendekatkan diri pada sang Maha Pencipta, Jokotole membakar dirinya untuk menghasilkan alat perekat yang keluar dari pusarnya. Itulah alat perekat terhebat yang berhasil mendirikan pintu gerbang kerajaan Majapahit yang menghalangi para musuh dari luar menerobos masuk ke dalam istana. Sejarah Jokotole memperlihatkan karakter mertèh atau miyara yang dalam kosa kata Indonesia sinonim dengan istilah rasa kepedulian untuk merawat kehidupan. Kemertèhan atau kepedulian bagi orang Madura bukan semata-mata memberikan perhatian kepada nasib orang lain, melainkan juga melibatkan rasa pengorbanan maupun spirit rela berkorban yang digerakkan oleh panggilan suara hati yang terdalam, sehingga kehidupan terbebas dari segala bentuk kerusakan.

Kemertèhan orang Madura berasosiasi dengan keiirian (èrèh) positif dan pengetahuan (ngartèh). Apabila ada orang lain yang gemar melakukan kebaikan, maka orang Madura akan merasa iri padanya. Iri pada konteks ini kehendak untuk menyetarakan diri dengan orang lain yang terbiasa berbuat baik kepada sesama dan lingkungan sekitarnya. Untuk mewujudkannya, membuat kehendak menyetarakan diri menjadi rutinitas hidup sehari-hari, dibutuhkan berbagai pengetahuan tentangnya, setidaknya mereka akan belajar kepada orang baik yang menjadi figur acuannya. Dua pertanyaan yang sering diajukan dalam proses belajar mengaktualisasikan diri berkehendak baik: mengapa itu dilakukannya dan bagaimana harus dilakukan. Misalnya, dalam hal bersikap sopan dengan cara membungkukkan badan (aghâlènon) saat melewati kumpulan orang-orang. Mungkin di daerah lain, kebiasaan seperti ini tidak dianggap lazim karena boleh jadi cara kesopanan menghadapi situasi yang sama sangat berbeda dengan cara yang dilakukan orang Madura. Tetapi, di Madura cara bersikap sopan seperti itu memicu kekaguman yang luar biasa, apalagi dilakukan oleh anak-anak muda yang dianggap tingkat pendidikannya melebihi orang tuanya. Orang Madura yang bersikap abai dengan kesopanan ini akan dianggap tak tahu diri karena tidak mengerti dunia kehidupan di mana mereka tinggal (ta' ngartèh ka alammah). Cara lainnya adalah kebiasaan menyapa (nyapah) orang lain yang telah saling mengenal ketika berpapasan di jalan. Ini juga sepadan dengan membungkukkan badan saat melewati kerumunan orang-orang yang sedang duduk bersantai. Korona telah menimbulkan sikap pencuriga antara satu orang dengan orang lain. Mereka dianggap 
berpotesi terpapar korona sebagai Orang Tanpa Gejala (OTG). Lebih dari itu, orang yang telah divonis positif secara medis mengidap korona biasanya cenderung menutup diri dari pergaulan karena merasa malu (maloh). Sehingga, kedua belah pihak berusaha saling menghindar atau menjauhkan diri. Tetapi, pandemi korona ini tetap tidak bisa menghalangi atau menghancurkan sikap kesopanan orang Madura. Sehingga, tatkala mereka berpapasan di jalan, sapaan hangat akan saling menguatkan menghadapi badai korona.

Meskipun tidak saling bertatap muka, bertegur sapa maupun sikap hormat (ngormad) serupa kepada orang lain di Madura masih dapat dilakukan dengan memanfaatkan kecangihan teknologi komunikasi, misalnya telepon genggam. Pada masa pandemi ini, terjadi peningkatan pemakaian telepon genggam. Hampir setiap orang Madura di masa sekarang ini memiliki kartu seluler lebih dari satu untuk mereka gunakan menelepon, mengirim pesan singkat berupa teks atau gambar, selain juga kebutuhan aktivitas daring. Hampir setiap hari, telepon genggam ini berisi panggilan telepon dan kiriman pesan singkat sebagai bentuk sapaan kepada orang-orang yang mereka kenal maupun kerabat dekat agar tetap bersemangat menjalani hidup di tengah-tengah dunia yang sedang sekarat. Aktivitas sosial pemakaian telepon genggam ini tidak pernah lagi dipikirkan tentang berapa banyak habisnya pulsa untuk menyapa orang-orang sekitarnya. Bagi orang Madura "pèssè bisa è sarèh, mon atèh tadâ' tokonah" (uang habis bisa dicari, tetapi merawat hati susah dicari). Kehidupan bagi orang Madura bukan tentang berburu kemegahan duniawi, karena sekali mati tidak bisa dibawa lagi. Kehidupan bagi orang Madura merupakan kepedulian mengasah dan merawat hati, karena hati menjadi sumber segala kebaikan dan itulah bekal untuk dibawa mati. Orang kaya atau berkuasa dihadapan orang Madura tetap diposisikan sebagai manusia yang patut dihormati. Tetapi, orang kaya atau berkuasa yang telah kehilangan hatinya karena tergoda oleh gemerlapnya duniawi akan membuat orang Madura menjaga jarak sosial dan budaya dengannya. Itu sebabnya, di masa pandemi korona muncul kebiasaan orang ter-ater (berbagi makanan kepada tetangga atau orang terdekatnya) hampir setiap hari. Bukan hanya di desa, di perkotaan Madura juga nyata. Inilah kemertèhan orang Madura yang berguna bagi semangat menjalani kehidupan di masa korona dan semoga terus terawat pasca korona.

\section{Ghetèh}

Di Madura, selama korona, siaran kematian di musholla kampung maupun masjid desa sering terdengar, baik pagi maupun malam hari. Hitungan kasar kami ketika tinggal di daerah perkampungan di pusat kota Pamekasan dan berkeliling mulai 
dari Patemon, Gurem, Parteker, Purba, hingga Kangenan, setidaknya setiap satu hari terdengar pengumuman kematian rata-rata sedikitnya tiga kali. Tidak semuanya penderita korona, tetapi para tetangga punya dugaan yang kuat bahwa kematiannya karena terpapar korona atau dikoronakan, bergejala atau tanpa gejala. Anak-anak muda di sekitar rumah duka segera berduyun-duyun menggali kubur di pemakaman umum. Para kerabat, teman, tetangga, atau rekan kerja almarhum/mah saling berbagi kesedihan dan mengatur waktu melayat atau menghadiri pemakamannya untuk mengirimkan doa sebagai bentuk penghormatan terakhir baginya. Sebagian dari mereka juga sibuk membantu tuan rumah selama tujuh hari ke depan, karena tahlilan (doa bersama untuk jenazah) sudah menjadi tradisi umum di Madura. Selama itu pula, para tamu akan datang secara terbatas untuk memberikan penguatan psikologis dan pesan kesabaran bagi keluarga yang ditinggalkan. Tradisi ini sering disebut lalabet (melayat). Tenda, kursi, dan tikar segera digelar oleh tetangga, anak muda, dan kerabat dekatnya seusai menggali kubur dan acara pemakaman telah dilakukan. Tokoh agama setempat, baik ustadz, ustadzah, kiai maupun nyai kampung, melaksanakan tugasnya mengurus jenazah hingga ke liang lahat. Ini semua merupakan keghetèan orang Madura yang barangkali jarang ditemukan di kota-kota besar yang masyarakatnya cenderung individual dan super sibuk dengan urusan pekerjaan industrial.

Ghetèh atau sepadan dengan ghesè' adalah upaya menyegerakan diri ketika berurusan dengan orang lain, baik dalam hal pekerjaan, pendidikan, kekeluargaan, pertemanan, hingga keagamaan. Orang Madura yang berkarakter ghetèh akan selalu berusaha tidak menunda atau mengulur-ulur waktu agar tidak membuat orang lain kecewa atau terluka hatinya. Secara lebih sederhana, keghetèan ini bertujuan untuk memudahkan urusan orang lain. Ghetèh sepertinya berbeda dengan sengkah (malas). Sengkah cenderung pada sikap hidup santai atau menikmati kualitas waktu luang individual tanpa merasa terusik atas kehadiran orang lain. Ketika diajak makan bersama oleh seorang teman, misalnya, dia boleh saja menolak karena sedang sengkah, sehingga orang sengkah tidak bisa dipaksa. Sedangkan, ghetèh berkaitan dengan cepat tanggap sosial sepanjang orang lain yang menjadi sasaran keghetèan tidak pernah perhitungan untung-rugi selama berinteraksi dengan orang-orang ghetèh. Jadi, keghetèan ini juga berbeda dengan penyelesaian target kerja yang sifatnya kontraktual. Penyelesaian target kerja kontraktual juga dituntut menyegerakan pekerja kantoran memenuhi tanggung jawab pekerjaannya. Hal seperti ini tidak termasuk dalam keghetèan orang Madura, karena ada unsur transaksional atau iming-iming jabatan, bukan atas dasar kehendak moral. Jika keghetèan digunakan dalam pekerjaan, maka 
orang Madura tidak pernah mempertimbangkan seberapa besar bayaran atau jabatan apa yang sedang mereka incar, melainkan karena memudahkan urusan orang lain bernilai kebaikan, sebagai ladang kedermawanan dalam hubungan resiprokal. Istilah lakoh (pekerjaan) bagi orang Madura tidak bisa diartikan semena-mena hanya berurusan kerja mencari uang saja. Kerja yang orientasinya mencari uang lebih dekat dengan istilah nyarè kasab, bukan lakoh. Dalam sehari-hari orang Madura selalu ada pertanyaan "bâdeh lakonah ? mon ade', nyo'on bhântowaanna". Pertanyaan ini bukan mengacu seseorang sedang bekerja di kantor atau tidak, sehingga perlu dimintai bantuan. Pertanyaan ini mengacu pada sedang sibuk tidaknya seseorang. Sibuk (bâdeh lakonah) berarti seseorang sedang mengerjakan sesuatu aktivitas: memperbaiki motor, genteng bocor, atau lainnya. Ketika mereka sibuk, maka keghetèan sedikit melamban dilakukan, tetapi pasti akan dilakukan setelah kesibukannya selesai."Rèng ghetèh nyerra otang, rèng ta' ghetèh andi' otang". Orang ghetèh akan mendapatkan balasan kebaikan, orang yang tidak ghetèh akan menanggung hutang kebaikan. Itu sebabnya, pada saat banyak kasus kematian di masa korona, orang Madura selalu melakukan keghetèan dengan berbagai macam bentuknya. Mereka tidak ingin menanggung hutang kebaikan di masa depan apabila peristiwa genting seperti kematian mengakibatkan terhambatnya orang melakukan keghetèan. Untuk mengantisipasi meledaknya kasus korona, orang Madura juga ghetèh dalam urusan kebersihan dan nyarè bhâlâ.

\section{Ressè}

Ressè' adalah karakter cinta bersih. Kategorisasi Ressè' dalam budaya orang Madura terbagi menjadi dua, yaitu sebagai tindakan sakral dan tindakan terpuji. Ressè' sebagai tindakan sakral berorientasi pada pemaknaan ibadah. Dalam hal ini, Ressè' tidak terbatas kebersihan fisik saja, melainkan juga kebersihan hati, budi, dan tutur kata. Selain itu, Ressè' dalam makna ibadah termanifestasi dalam bentuk bersih makam dan rumah. Bersih-bersih makam menjadi tradisi sakral orang Madura yang disebut dengan Sar-kosar. Lebih dari itu, Sar-kosar juga bisa dilakukan setiap kamis sore sebagai bagian dari rangkaian kegiatan nyalasè atau ziarah kubur. Tetapi, di masa korona, ziarah kubur meningkat dari biasanya. Hampir setiap hari di Bangkalan terlihat pergi berziarah. Mereka merasa rindu dengan sanak keluarga yang meninggal karena korona. Ini juga bisa menjadi pengingat kepada yang masih hidup, sehingga mendorong cinta kebersihan supaya tidak menjadi korban keganasan virus korona berikutnya. Sementara, ressè' juga bermakna tindakan terpuji. Menjadi terpuji karena bersandar pada ajaran Islam: "kebersihan sebagai bagian dari iman". Ressè' ini 
menghadirkan harapan kebersihan jiwa agar terhindar dari segala "kotoran" kehidupan. Ressè' berporos pada pikiran bersih, sehingga menghasilkan tindakan terpuji, setidaknya bisa menginspirasi orang lain. Lebih dari itu, ressè' memunculkan kesadaran pentingnya kepedulian, keimanan, keikhlasan, kerja keras, dan kebersihan hati.

Di masa pandemi, karakter ressè' orang Madura terlihat intensif pada aktivitas bersih-bersih makam. Dari yang awalnya setahun sekali, menjadi satu bulan dan bahkan satu minggu satu kali. Selain itu, kesadaran untuk sterilisasi rumah dari bahaya korona mulai muncul dengan adanya penyemprotan disinfektan dan ketersediaan handsanitaizer di tiap-tiap rumah orang. Namun, menjaga jarak fisik belum sepenuhnya dianggap penting bagi orang Madura. Di daerah Bangkalan, tradisi tahlil hampir terjadi setiap hari, dari sore hingga malam, karena banyaknya kasus kematian akibat korona. Bagi mereka, tahlilan juga bagian upaya pembersihan rohaniah. Dengan mengingat kematian, kita menyadari bahwa manusia harus sebisa mungkin berprilaku bersih lahirbatin sebagai bekal kembali pulang menuju Tuhan. Karakter ressè' menjadi bagian prilaku keislaman orang Madura. Banyaknya sanak saudara yang meninggal mendorong orang Madura di perantauan untuk pulang kampung (toron). Mereka pulang kampung karena tidak ingin terpapar korona di kota besar yang padat penduduk, selain juga menjaga imunitas tubuh karena alam Madura masih belum banyak terkontaminasi polusi.

\section{Nyarè Bhâlâ}

Nyarè bhálá adalah karakter berpetualang untuk memperkuat ikatan saudara sedarah di Madura. Di masa krisis seperti pandemi ini, konsep nyarè bhálá menjadi modal sosial ekonomi. Karena, nyarè bhálá berfungsi bala bantuan paling efektif bagi orang Madura yang mengalami krisis ekonomi akibat terjangan korona. Ikatan darah yang awalnya renggang perlahan menguat sehingga hubungan mereka semakin akrab. Akan tetapi, nyarè bhálá dalam orientasi ekonomi tidak bertendensi negatif. Nyarè bhálá dalam artian ini memberi sinyal adanya kesulitan antar saudara dan menghadirkan kepedulian sesama keluarga. Orang Madura menghadirkan karakter nyarè bhálá dengan dimensi baru. Wajah yang menatap sekaligus memprediksi sejarah masa depan. Nyarè bhálá dalam pemahaman orang Madura sebelum krisis hanya dimaknai sebagai silaturahmi. Akhirnya, nyarè bhálá ini sebatas dilakukan agar memeriahkan suatu momentum, semisal hari raya. Namun, nyarè bhálá di tengah krisis tidak hanya bermakna silaturahmi saja. Melainkan juga, mengantisipasi terjadinya kemiskinan temporal dan keputusasaan menjalani hidup yang penuh ketidakpastian. 
Bhálá adalah tempat utama bagi orang Madura mencurahkan kepahitan hidupnya. Setidaknya, curahan hatinya bisa meminimalisir beban psikologis mereka.

Nyarè bhálá sulit lepas dari tradisi kelslaman. Tahlilan merupakan momentum nyarè bhálá yang mudah terkoordinasikan secara sosial. Tahlilan ini menjadi ruang pengkayaan bagi karakter nyarè bhálá orang Madura. Tahlilan ini biasanya dilakukan selama 7 hari penuh. Selama 7 hari inilah upaya nyarè bhálá bisa sesegera mungkin dilakukan. Tradisi keagamaan tahlil cukup membantu anak muda menelusuri silsilah bhálá yang pada kondisi hidup normal dimaknai 'saudara jauh', jarangnya pertemuan. Intensitas tahlilan yang tinggi di masa pandemi inilah membuat perjumpaan di antara bhálá yang jauh semakin dekat.

\section{SIMPULAN}

Orang Madura bukan homo dupleks, "Saya dan Kita", yang menurut Durkheim, puncak tertingginya menyatunya individu dengan homogenitas sistem sosial. Orang Madura, tidak mungkin digolongkan hanya sebatas homo dupleks, terutama pada saat mereka menghadapi situasi krisis, seperti korona yang kehadirannya tidak pernah kita duga sebelumnya. Mereka ibarat rujak yang bahan utamanya beraneka rupa, diolah dengan cara berbeda, dan memiliki sifat yang berbeda pula. Kendati kesemua bahan direkatkan oleh petis, setiap bagian bahan utamanya tetap terasa nikmat jika dimakan terpisah. Dengan kata lain, karakter orang Madura di masa korona ini menunjukkan kompleksitas yang sedemikian rupa, sehingga muncul lima karakter berbeda-beda, sekalipun semua karakter ini berasosiasi dengan dunia kehidupan orang Madura. Lima karakter krisis orang Madura ini adalah pènal, mertèh, ghetèh, nyarè bhâlâ, dan ressè'. Kesemuanya merupakan moralitas orang Madura yang dalam situasi normal mungkin intensitasnya tidak semenonjol daripada masa-masa krisis. Secara filosofis, kelima karakter krisis orang Madura ini mengacu pada imperatif kategoris, dialektis, dan kehendak berkuasa (kehendak menyetarakan diri). Sehingga, pengalaman hidup orang Madura sulit diposisikan sebagai tuan-majikan, karena pemahaman mereka tentang pekerjaan tampak berbeda dengan konsep kerja menurut Hegellian. Relasi tuan-budak juga tidak selalu menunjukkan keseluruhan dunia orang Madura. Kendati orang Madura pada situasi krisis memegang prinsip "Ya, pada hidup", mereka juga mempertimbangkan suara hatinya ketika harus berhadapan dengan kasus kematian. Secara sosiologis, mereka juga rela berkorban sebagai pengorbanan substitusional maupun resiprokal. Melalui spirit berkorban dan pengorbanan inilah orang Madura tak ingin mengulur waktu untuk mempererat hubungan kekeluargaan yang sebelumnya 
biasa dilakukan saat lebaran saja. Cinta kebersihan yang dulunya memudar karena sering dibebankan kepada perempuan, kini cinta kebersihan dilakukan oleh semua orang. Tidak hanya berfokus kebersihan badaniah, tetapi juga kebersihan batiniah. Tidak hanya lingkungan alam, melainkan juga dunia kehidupan.

\section{Ucapan Terima Kasih}

Tulisan ini adalah hasil penelitian lapangan mandiri, tanpa ada bantuan subsidi institusional maupun industrial, dan dilakukan di sela-sela kami pulang kampung. Oleh karena itu, kelancaran penelitian lapangan yang menghasilkan data dan pembahasan pada tulisan ini sebagian besar berasal dari kebaikan hati para informan di lapangan serta bantuan moral kolegalial, selain juga pengamatan intensionalitas kami. Kerelaan mereka, dengan tingkat kepercayaan yang tinggi di antara kami, merupakan sesuatu kemewahan di tengah badai korona yang hingga detik ini masih melanda seluruh dunia, termasuk Madura. Itu sebabnya, kami sepantasnya mengucapkan terima kasih tidak terhingga kepada mereka semua yang ikut berperan bagi kelancaran penelitian ini hingga menjadi sebongkah berlian gagasan yang bisa kami sajikan untuk pembaca dan penikmat ilmu sosial budaya, terutama ilmu sosial budaya masyarakat Madura. Mator sakalangkong! Sala lopot, nyo'onna sapora.

\section{DAFTAR RUJUKAN}

Abdullah, M. A. (1992). The Idea of Universality of Ethical Norm in Ghazali and Immanuel Kant. Ankara: Turkiye Diyanet Vaksi.

Aerts, D., D'hooghe, B., \& Note, N. (Eds). (2005). Worldview, Science, and Us. Singapore, New Jersey \& London: World Scientific.

Bellah, R. (1973). Introduction. In Durkheim, E. On Morality and Society (pp. Ix - Lv). Chicago and London: The University of Chicago Press.

Bey, A. D. (2012). Peran Budaya/Kebudayaan Dalam Menemukan Kembali Karakter Madura yang Hilang. Sumenep: Panitia Kongres Kebudayaan Madura II.

Collins, R. (1975). Conflict sociology: Toward an Explanatory Science. New York: Academic Press.

Collins, R. (2009). Conflict Sociology: A Sociological Classic Updated. London:

Paradigm Publishers Boulder

Damon, W., \& Colby, A. (2015). The Power of Ideals. New York: Oxford University Press.

Deleuze, G. (1984). Kant's Critical Philosophy. London: The Athlone Press.

Deleuze, G. (1986). Nietzche and Philosophy. London \& New York: Continuum.

Dodd, J. (2004). Crisis And Reflection. New York: Kluwer Academic Publishers.

Dort, T. B. (1898). Historische Studie over Lepra: Voornamelijk in Verband met het Voorkomen Dezer Ziekte in.

Durkheim, E. (1953). Sociology and Philosophy. London: COHEN \& WEST Ltd.

Durkheim, E. (1954). The Elementary Forms of The Religious Life. Glencoe, IL: Free Press. 
Durkheim, E. (1982). The Rules of Sociological Method. New York: The Free Pres.

Encyclopaedie Van Nederlandsch Indie, Tweede. (1918). Deel H-M.

Freud, S. (1962). Civilization and Its Discontent. New York: WW. Horton \& Company. Inc.

Gadamer, H. G. (1976). Hegel's Dialectic. New Haven \& London: Yale University Press.

Gellner, E. (1981). Muslim Society. Cambridge: Cambridge University Press.

Giddens, A. (1971). Capitalism And Modern Social Theory, UK: Cambridge University Press.

Girard, R. (1977). Violence and The Sacred, USA: The Johns Hopkins University Press.

Girard, R. (1986). The Scapegoat. USA: The Johns Hopkins University Press.

Grenberg, J. (2005). Kant and The Ethics of Humanity. UK: Cambridge University Press.

Hall, et.al. (1978). Policing The Crisis Mugging: The State, And Law And Order. London And Basingstoke: The Macmillan Press Ltd.

Hatab, L. J. (2008). Nietzche's On The Genealogy of Morality. New York: Cambridge University Press.

Howard, D. A. (2011). Being Human In Islam. London \& New York: Routledge.

Hunt, L. H. (1991). Nietzche and The Origin of Virtue. London \& New York: Routledge.

Hunter, D. J. (1991). Culture War. New York: Basic Books.

Hunter, D. J. (2000). The Death of Character. New York: Basic Books.

Hunter, D.J. (2010). To Change The World. New York: Oxford University Press.

Husserl, E. (1965). Phenomenology and The Crisis of Philosophy. New York: Harper

Torchbooks.

Husserl, E. (1970). The Crisis of European Sciences and Transcendental

Phenomenology, USA: Northwester N University Press.

Husserl, E. (1999). The Idea of Phenomenology. New York: Kluwer Academic Publishers.

Husserl, E. (2001). The Shorter Logical Investigations. London: Routledge.

Hutcheon, P. D. (1999). Building Character and Culture. USA: PRAEGER

Kerstein, S. J. (2002). Kant's Search For The Supreme Principle of Morality. UK:

Cambridge University Press.

Kupperman, J. J. (1991). Character. New York: Oxford University Press.

Kupperman, J. J. (1999). Value ... and What Follows. New York: Oxford University Press.

Kupperman, J. J. (2007). Ethics and Qualities of Life. New York: Oxford University Press.

Lyman, S. M, \& Scott, M. B. (1989). A Sociology of The Absurd. New York: General Hall Marcuse, H. (1941). Reason and Revolution. London: Routledge \& Kegan Paul Ltd.

Naugle, D. K. (2002). Worldview: The History of a Concept. UK: William B. Eerdmans Publishing Company.

Nietzche, F. (1968). Will to Power. New York: Vintage Books.

Nietzche, F. (1974). The Gay Science. New York: Vintage Books.

Nietzche, F. (1989). On The Genealogy of Moral. New York: Vintage Books.

Nietzche, F. (1997). Daybreak. New York: Cambridge University Press.

Owen, D. (2007). Nietzche's Genealogy of Morality. UK: Acumen.

Piaget, J. (1947). The Psychology of Intelligence, London \& New York: Routledge.

Raditya, A. (2021). Modal Budaya Menghadapi Korona Madura (24 Juni, Hal. 4). Jawa Pos.

Reath, A. (2006). Agency and Autonomy in Kant's Moral Theory. New York: Clarendon Press.

Riesman, D. (1961). The Lonely Crowd. New Haven \& London: Yale University Press.

Rifai. M.A. (2007). Manusia Madura. Yogyakarta: Pilar Media. 
Rose, G. (1981). Hegel Contra Sociology. London \& Atlantic Highlands: Athlone.

Ryan, K. B., \& Thayer, J. D. (1996). Character Education Manifesto. Boston: The Center For The Advancement of Ethics and Character.

Sadik, S. A. (2017). Penyusunan Bahan Ajar dan Penguatan Pendidikan Karakter. Jakarta: Kemendikbud.

Sartre, J. P. (1948). The Emotions: Outline of a Theory. New York: Philosophical Library.

Schwartz, A. J. (2002). Transmitting Moral Wisdom In An Age of Autonomous Self. In Damon, W. (Eds.). Bringing In A New Era In Character Education (pp. 1 - 22). California: Hoover Institution Press.

Setiawan, E. (2007). Menegakkan Kembali Citra Budaya Madura. Sumenep: Panitia Kongres Kebudayaan Madura I.

Sire, J. W. (2004). Naming The Elephant: Worldview as a Concept. Illinois: IVP Academic.

Skinner, B. F. (1971). Beyond Freedom and Dignity. USA: Penguin Books.

Skinner, B. F. (2005). Science and Human Behavior. USA: Free Press.

Smagorinsky, P., \& Taxel, J. (2005). The Discourse of Character Education. Mahwah, New Jersey \& London: LEA Publisher.

Thero, D. P. (2006). Understanding Moral Weakness. Amsterdam \& New York: Rodopi.

Thomson, I. T. (2010). Culture War and Enduring American Dilemmas. USA: The University of Michigan Press.

Turner, B. (1974). Max Weber Classic Monographs, Volume VII: Weber and Islam. London \& New York: Routledge.

Turner, B. S. (1992). Interpreting Emile Durkheim (Introduction). In Durkheim, E. Professional Ethics and Civic Morals (pp. Xiii - Xlii). London \& New York: Routledge.

Turner, S. P. (Eds.). (1993). Emile Durkheim: Sociologist and Moralist. London \& New York: Routledge.

Verene, D. P. (2007). Hegel's Absolute. USA: State University of New York Press.

Weber. M. (1978). Economy and Society. Los Angeles \& London: University of California Press.

Weber. M. (1992). The Protestant Ethic and The Spirit of Capitalism, London and New York: Routledge.

Williams, L. L. (2001). Nietzche's Mirror. USA: Rowman \& Littlefield Publisher Inc.

Wiyata, L. (2007). Benarkah Orang Madura Keras ?. Sumenep: Panitia Kongres Kebudayaan Madura I.

Wood, A. W. (1990). Hegel's Ethical Thought. New York \& Australia: Cambridge University Press.

Zahavi, D. (2003). Husserl's Phenomenology. California: Stanford University Press Stanford. 